\title{
ANALISIS DESAIN ILUSTRASI KEMASAN BERAS ECOKO GREEN PROJECT MELALUI KAJIAN SEMIOTIKA
}

\author{
I Putu Adi Natha \\ Desain Komunikasi Visual, Penciptaan dan Pengkajian Seni \\ Pasca Sarjana Institut Seni Indonesia Yogyakarta \\ e-mail : iputuadinatha@gmail.com \\ Diterima : 23 April 2020. Disetujui : 25 November 2020. Dipublikasikan : 1 Desember 2020
$\begin{aligned} & \text { (c) () } 92020 \text { - DESKOVI Universitas Maarif Hasyim Latif. Ini adalah artikel dengan akses } \\ & \text { terbuka di bawah lisensi CC BY } 4.0 \text { (https://creativecommons.org/licenses/by/4.0/) }\end{aligned}$
}

\begin{abstract}
ABSTRAK
Tulisan ini dibuat guna memahami tanda makna komunikasi visual yang terdapat pada ilustrasi kemasan beras dari Ecoko Green Project, serta pesan komunikasi visual yang terkandung pada ilustrasi pada kemasan beras tersebut. Pengumpulan data dalam penelitian ini dilakukan dengan cara observasi dengan datang ke studio Oka Astawa dan mendapatkan foto-foto mengenai kemasan beras yang berisi karya dari Oka Astawa. Data yang terkumpul kemudian dianalisis dengan menggunakan analisis kualitatif dari teori semiotika Charles Sanders Pierce ikon, indeks, dan simbol. Hasil penelitian tersebut menunjukkan bahwa 1.) Ikon pada ilustrasi kemasan beras Ecoko Green Project adalah penggambaran petani itu sendiri karena memiliki kemiripan dengan bentuk aslinya yaitu penggambaran seorang petani. 2.) Indeks pada ilustrasi kemasan beras tersebut adalah penggambaran gedung dan jalan pada tubuh petani pertama, serta dolar dan padi yang tidak seimbang pada ilustrasi kedua merupakan penggambaran sebab akibat. 3.) Simbol pada ilustrasi kemasan beras tersebut adalah caping (topi petani) serta padi pada ilustrasi kemasan beras yang pertama dan kedua merupakan simbol dari pertanian itu sendiri, dan pada ilustrasi kemasan kedua ada dua simbol tambahan yaitu dolar dan dasi berbentuk ular, dimana kedua simbol tersebut menggabarkan petani ditindas oleh uang dan penguasa.
\end{abstract}

Kata kunci: Ecoko Green Project, Ilustrasi, Kemasan, Pertanian, Semiotika

\begin{abstract}
This paper is made to learn the meaning sign of the visual communication that contained in the illustration of rice packaging from the Ecoko Green Project, as well as the visual communication message in that illustration on the rice packaging. The collected data in this study was carried out with observation by coming to the Oka Astawa studio and getting photos of rice packaging containing the works of Oka Astawa. The collected data is then analyzed using qualitative analysis and Charles Sanders Pierce's semiotic theory of icons, indexes, and symbols. The results of these studies indicate that 1.) The icon in the Ecoko Green Project rice packaging illustration is a description of the farmer itself because it has a similarity to the original form, which is the description of a farmer. 2.) The index in the illustration of rice packaging is the depiction of buildings and roads in the body of the first farmer, then the dollar and rice that is not balanced in the second illustration are depictions of cause and effect. 3.) The symbol in the illustration of the rice packaging is the caping (farmers' hat) and the rice in the first and second illustration of the rice packaging is a symbol of the agriculture itself, and in the second packaging illustration there are two additional symbols, the dollar and a snake-shaped tie, where both of the symbols described that the farmers being oppressed by money and the authority.
\end{abstract}

Keyword: Agriculture, Ecoko Green Project, Illustration, Packaging, Semiotics

\section{PENDAHULUAN}

Kemasan adalah desain kreatif yang mengaitkan bentuk, struktur, material, warna, citra, tipografi dan elemen-elemen desain dengan informasi produk agar produk dapat dipasarkan. Kemasan digunakan untuk membungkus, melindungi, mengirim, mengeluarkan, menyimpan, mengidentifikasi dan membedakan sebuah produk di pasar (Klimchuk dan Krasovec, 2006:33).

Menurut Kotler \& Keller (2009:27), pengemasan adalah kegiatan merancang dan memproduksi wadah atau bungkus sebagai sebuah produk. Pengemasan adalah aktivitas merancang dan memproduksi kemasan atau pembungkus untuk produk. Biasanya fungsi utama dari kemasan adalah untuk menjaga produk. Namun, sekarang kemasan 
menjadi faktor yang cukup penting sebagai alat pemasaran (Rangkuti, 2010:132).

Banyak perusahaan yang sangat memperhatikan kemasan suatu barang sebab mereka menganggap bahwa fungsi kemasan tidak hanya sebagai pembungkus, tetapi jauh lebih luas dari pada itu. Simamora (2007) mengemukakan pengemasan mempunyai dua fungsi yaitu:

\section{Fungsi Protektif}

Berkenaan dengan proteksi produk, perbedaan iklim, prasarana transportasi, dan saluran distribusi yang semua berimbas pada pengemasan. Dengan pengemasan protektif, para konsumen tidak perlu harus menanggung risiko pembelian produk rusak atau cacat. 2. Fungsi Promosional

Peran kemasan pada umumnya dibatasi pada perlindungan produk. Namun kemasan juga digunakan sebagai sarana promosional. Menyangkut promosi, perusahaan mempertimbangkan preferensi konsumen menyangkut warna, ukuran, dan penampilan.

Saat ini salah satu desain kemasan yang unik menurut penulis adalah kemasan beras Ecoko Green Project karya dari I Gede Oka Astawa, mahasiswa lulusan dari Fakultas Seni Rupa Institut Seni Indonesia Yogyakarta. Karya yang dibuat oleh Oka Astawa ini tujuannya tidak hanya sekedar untuk melindungi isi produk dan meningkatkan nilai jual produk tersebut. Desain kemasan beras Ecoko Green Project karya Oka Astawa ini juga mempunyai tujuan lain yaitu kritik sosial untuk menyuarakan isu-isu seputar pertanian.

Karena kebudayaan Bali dibentuk oleh kebudayaan agraris atau pertanian. Secara historis pertanian merupakan ibu dari peradaban Bali. Subak merupakan sistem pertanian berbasis kearifan lokal Bali yang telah diakui oleh dunia. Subak bukan sematamata sebagai sistem irigasi, namun di dalamnya terdapat aspek kebudayaan menyeluruh meliputi aspek religi, sistem sosial kultural yang meliputi segala aspek kehidupan masyarakat petani sebagai pendukung utama dari peradaban agraris ini.

Namun seiring berjalannya waktu, ada begitu banyak hal yang berubah dalam memori kultural masyarakat Bali. Kehidupan sosial yang dipengaruhi oleh industri dan pariwisata mengubah pola perilaku masyarakat Bali. Alih fungsi lahan terjadi atas nama pengembangan infrastruktur industri pariwisata yang kian masif. Lahan-lahan pertanian berubah menjadi bangunan-bangunan hotel, vila, perumahan, jalan raya dan berbagai infrastruktur lainnya.

Menurut Kepala Dinas Tanaman Pangan, Hortikultura dan Perkebunan Provinsi Bali yang dikutip pada IDN Times Bali pada tanggal 19 Oktober 2018, Ida Bagus Wisnuardhana mengungkapkan, alih fungsi lahan pertanian yang terjadi di Bali pada tahun 2017 mencapai 900 hektare. Jumlah tersebut setara 1,13 persen dari total luas lahan pertanian yang mencapai 78.626 hektare.

Oka berharap dari gerakan Ecoko Green Project ini dapat menyampaikan gagasan serta kepeduliannya terhadap pertanian di Bali. Kepedulian disini bukan hanya sebatas alih fungsi lahan, tetapi bagaimana anakanak muda di Bali mau bertani atau mau melanjutkan profesi orangtuanya sebagai petani. Karena yang bertani di Bali saat ini sebagian besar adalah orang tua dan masih jarang anak-anak muda di Bali mau menekuni profesi sebagai petani karena merasa gengsi.

Untuk itu Oka menuangkan gagasannya kedalam karya senin dengan memakai medium kemasan beras untuk direspon. Maka hadirlah karyakarya drawing, yang diproduksi dengan teknik cetak saring, kemudian diterapkan pada medium kemasan beras sebagai ilustrasi pendukung untuk produk beras tersebut, dimana ilustrasi ini tujuannya bukan hanya untuk menjadi daya Tarik untuk meningkatka harga jual, melainkan untuk menyuarakan kritik sosial isu-isu seputar pertanian.

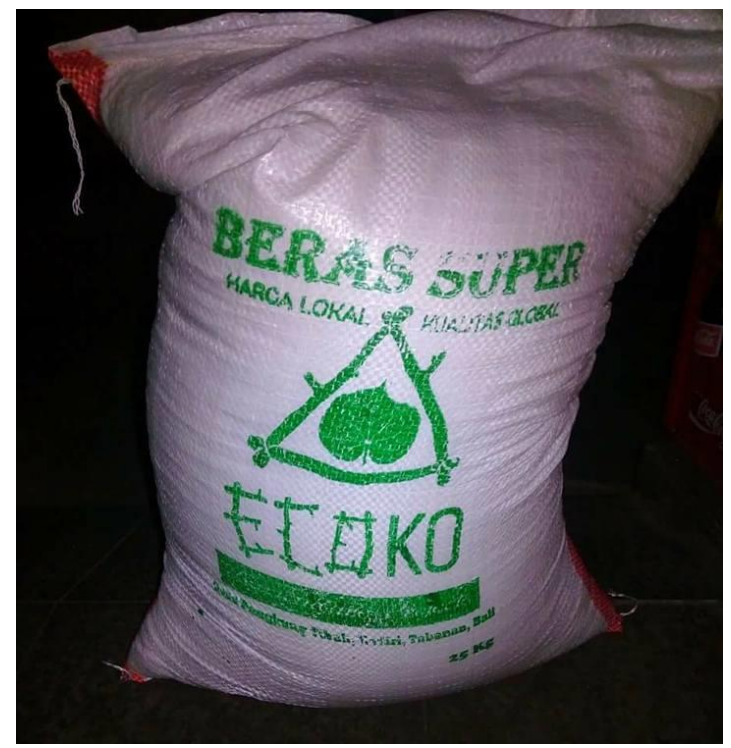

Gambar 1. Logo Beras Ecoko Green Projrc Sumber: Oka Astawa

Krititik sosial merupakan sebuah inovasi, artinya kritik sosial menjadi sarana komunikasi gagasan baru di samping menilai gagasan lama untuk suatu perubahan sosial. Kritik sosial sebagai salah satu bentuk komunikasi dalam masyarakat yang bertujuan atau berfungsi sebagai kontrol terhadap jalannya sebuah sistem sosial atau proses bermasyarakat (Oksinata, 2010:33).

Selain ditampilkan di sebuah galeri sebagai karya instalasi, kemasan beras Ecoko Green Projec ini memang benar-benar diterapkan untuk membungkus beras. Produk beras yang dibungkus berasal dari hasil panen sawah milik keluarganya dan sawah sekitar desa Pangkungtibah. Dengan kemasan yang unik ini dapat meningkatkan harga jual, ketimbang gabah hasil panen tersebut dijual kepada tengkulak. Dalam penjualan produk berasnya ini juga meliputi kegiatan sosial dimana pengumpulan 15 karung beras isian $25 \mathrm{~kg}$ untuk donasi 10kg ke masyarakat yang membutuhkan.

Pada penelitian ini penulis ingin mengetahui makna dibalik ilustrasi kemasan beras Ecoko Green Project karya dari Oka Astawa. Ilustrasi pada kemasan 
beras Ecoko Green Project karya dari Oka Astawa menarik untuk diteliti karena mempunyai tema yang konsisten, unik, karakteristik yang tegas, dan jelas.

Rumusan masalah dari penelitian adalah menganalisis makna ilustrasi pada kemasan beras Ecoko Green Project karya Oka Astawa menggunakan teori semiotika Charles Sanders Peirce.

Lebih jauh lagi analisis karya ini dilakukan dalam rangka ikut berkontribusi memberikan pemahaman di lingkungan akademis akan pentingnya peran semiotika dalam bidang visual dan bagaimana sistem tanda bekerja dalam karya.

\section{METODE PENELITIAN}

Penelitian ini menggunakan metode deskriftif kualitatif. Dalam penelitian ini dirancang suatu metode penelitian yang sesuai dengan masalah dan tujuan penelitian yang berguna untuk membantu dalam menentukan metode pengumpulan data dan analisisnya. Metode penelitian ini meliputi, (1) Prosedur penelitian, (2) Subjek dan objek penelitian, (3) Jenis dan sumber data, (4) Metode pengumpulan data, dan instrument, (5) Analisis data, (6) Kesimpulan.

Jenis data dalam penelitian ini adalah data primer, dan sekunder data primer berupa desain fisik karya ilustrasi pada kemasan beras Ecoko Green Project yang diperoleh dari Oka Astawa, sedangkan data sekunder adalah data yang diperoleh dari sumber data primer yang telah diolah lebih lanjut dan disesuaikan dengan pembahasan analisis semiotika.

\section{Teknik Pengumpulan Data}

a. Observasi, yaitu penulis melibatkan diri langsung dengan objek yang diteliti yaitu ilustrasi pada kemasan beras Ecoko Green Project. Hal ini dilakukan supaya peneliti sebagai instrumen utama dapat memahami objek yang diteliti dan dapat memberikan penilaian.

b. Dokumentasi, yaitu penulis mengumpulkan data dan informasi tentang objek penelitian. Dokumentasi ini dilakukan dengan mengumpulkan data berupa foto dari ilustrasi kemasan beras Ecoko Green Project.

c. Studi Literatur, mencari dan mengumpulkan literatur yang berhubungan dengan ilmu semiotika, guna relevansi sumber dalam rangka interpretasi karya. Selain literatur pokok tentang semiotika, penulis juga menggunakan pustaka pendukung seperti teori desain kemasan, dan sumber webtografi/internet.

d. Wawancara, penulis melakukan wawancara langsung dengan Oka Astawa selaku penggagas Ecoko Green Project ini, guna mengetahui tujuan untuk apa gerakan ini dibuat.

\section{Analisis Data}

Guna mengungkap data tersebut dilakukan langkah analisis model semiotika
Peirce yang menggolongkan tanda menjadi ikon, indeks dan simbol.

\section{HASIL DAN PEMBAHASAN}

Analisis penelitian ini difokuskan pada dua ilustrasi kemasan beras Ecoko Green Project karya Oka Astawa yang bertema "Save Petani", dimana dua karya tersebut berjudul "Darurat Agraria dan "Petani Tercekik". Karya-karya yang sudah ditentukan sebagai data penelitian, teridentifikasi sebagai karya ilustrasi pada kemasan beras Ecoko Green Project.

Pada pembahasan ini penulis menggunakan landasan semiotika Peirce yang menggolongkan tanda menjadi ikon, indeks dan simbol. Kris Budiman (2011: 20-22) menjelaskan ikon, indeks dan simbol sebagai berikut, (1) Ikon merupakan tanda yang mengandung kemiripan visual dengan obyek yang diwakilinya. (2) Indeks, merupakan tanda yang memiliki hubungan sebab-akibat dengan apa yang diwakilinya atau disebut juga tanda sebagai bukti. (3) Simbol, merupakan jenis tanda yang bersifat arbitrer dan konvensional.

\section{Ilustrasi Darurat Agraria}

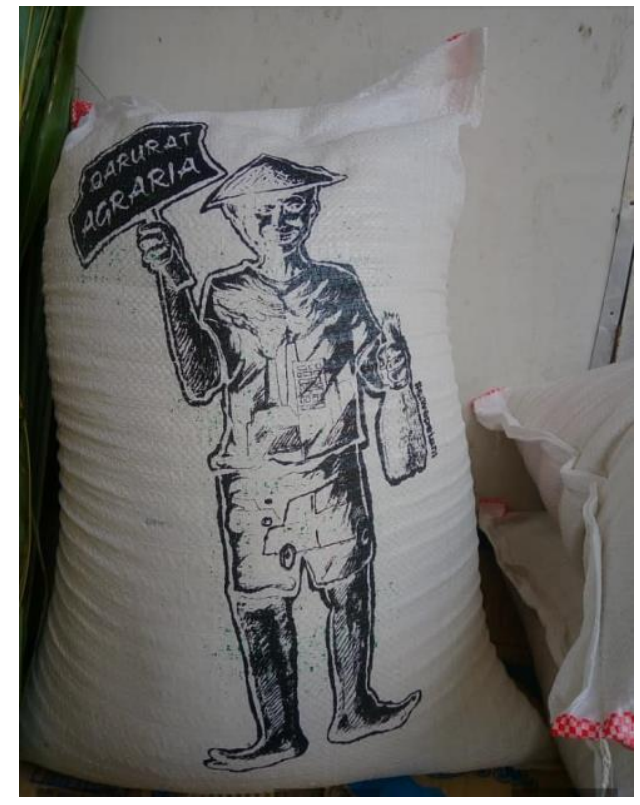

Gambar 2. Ilustrasi Darurat Agraria Sumber: Oka Astawa

a. Ikon, terdapat ikon pada kemasan beras ini yaitu ilustrasi gambar manusia memakai caping (topi petani), memegang tulisan "Darurat Agraria" dan satu tangan lainnya menggenggam seikat padi. Ilustrasi tersebut digolongkan ikon karena memiliki kemiripan dengan bentuk aslinya yaitu penggambaran seorang petani. Pada tagar yang bertuliskan \#savepetani di dalam ilustrasi juga bisa disebut ikon, tagar savepetani dapat dikatakan sebagai ikon sebab kata tersebut menggantikan objeknya yaitu petani itu sendiri. 
b. Indeks, terdapat indeks pada kemasan beras ini yaitu ilustrasi gambar manusia memakai caping (topi petani), memegang tulisan "Darurat Agraria" dan satu tangan lainnya menggeggam seikat padi, dimana pada tubuh atau pakaian dari petani tersebut digambarkan dengan gedung industri yang padat serta kendaraan yang mengakibatkan polusi. Penggambaran tersebut dapat dikatakan sebagai indeks karena adanya hubungan sebab-akibat dimana petani tersebut juga secara tidak langsung mewakili sawah sebagai lahan pertanian yang mana saat ini sawah di Bali telah beralih fungsi menjadi gedung-gedung yang padat serta jalanan denga kendaraannya yang menyebabkan polusi, dimana pada akhirnya menyebabkan darurat agraria

c. Simbol, terdapat simbol pada kemasan beras ini yaitu caping (topi petani) yang identik dan sering digunakan oleh petani. Kemudian padi adalah hasil dari produk pertanian itu sendiri. Jadi kedua gambar tersebut mewakili pertanian dan dapat dikatakan sebagai simbol.

\section{Ilustrasi Petani Tercekik}

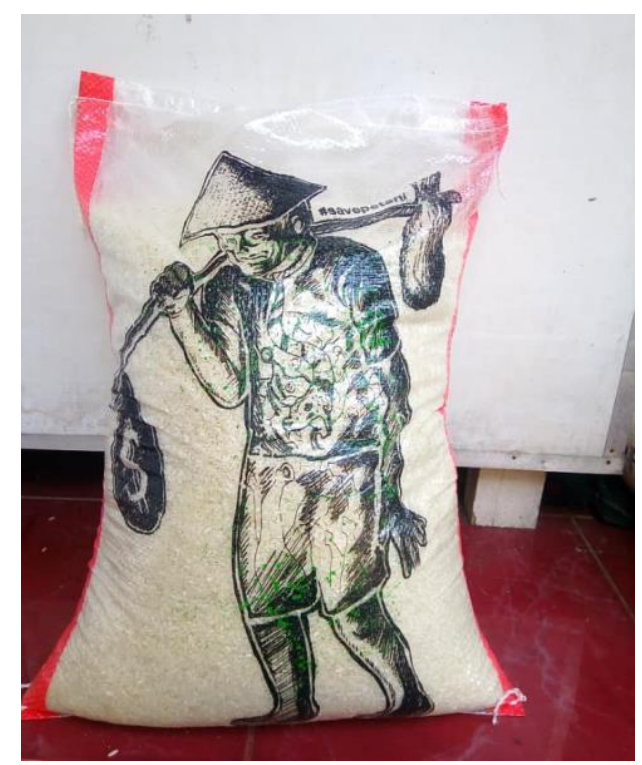

Gambar 3. Ilustrasi Petani Tercekik Sumber: Oka Astawa

a. Ikon, terdapat ikon pada kemasan beras ini yaitu ilustrasi gambar manusia memakai caping (topi petani), sedang memikul padi dan dolar, ilustrasi tersebut digolongkan ikon karena memiliki kemiripan dengan bentuk aslinya yaitu penggambaran seorang petani. Pada tagar yang bertuliskan \#savepetani di dalam ilustrasi juga bisa disebut ikon, tagar savepetani dapat dikatakan sebagai ikon sebab kata tersebut menggantikan objeknya yaitu petani itu sendiri.

b. Indeks, terdapat indeks pada kemasan beras ini yaitu ilustrasi gambar manusia memakai caping (topi petani), sedang memikul padi dan dolar. Gambar ilustrasi petani memikul padi dan dolar dikatakan sebagai indeks karena adanya hubungan sebab-akibat yaitu harga dolar dan padi tidak berimbang dimana digambarkan dolar lebih berat dari padi, sehingga banyak petani terpaksa menjual lahan sawahnya karena dolar lebih unggul serta berkuasa. Oleh sebab itu keadaan ini juga mengakibatkan petani tercekik yang digambarkan dasi berbentuk ular yang melilit di leher petani tersebut.

c. Simbol, terdapat simbol pada kemasan beras ini yaitu caping (topi petani), dan padi dimana kedua gambar tersebut merupakan simbol dari pertanian, serta terdapat simbol lain yaitu dolar dan dasi berbentuk ular. Dolar adalah simbol uang, dimana uang bisa dingunakan membeli apa saja yang diinginkan termasuk membeli sawah dan merubahnya menjadi Gedung-gedung serta jalan. Kemudian dasi berbentuk ular merupakan simbol dari pengusaha atau penguasa yang memiliki sifat seperti ular melilit serta mencekik petani sebagai rakyat kecil.

\section{PENUTUP}

Dapat disimpulkan bahwa tanda-tanda makna komunikasi visual dalam karya ilustrasi pada kemasan beras Ecoko Green Project merupakan sebuah bentuk keprihatinan Oka Astawa terhadap petani dan lahan pertanian di Bali yang mana kian hari kian menyempit karena sawah telah beralih fungsi menjadi gudunggedung dan jalanan yang dipadati kendaraan yang mengakibatkan polusi. Adapun kedua karya ilustrasi pada kemasan beras Ecoko Green Project tersebut berdasarkan teori Charles Sanders Peirce terdapat tanda berupa Ikon, Indeks, Simbol yang dapat dijelaskan sebagai berikut:

1. Ikon berupa manusia memakai caping (topi petani), memegang tulisan "Darurat Agraria" dan satu tangan lainnya menggenggam seikat padi pada ilustrasi kemasan beras yang pertama. Serta manusia memakai caping (topi petani) sedang memikul dolar dan padi pada ilustrasi kemasan beras kedua. Dua ilustrasi dari kemasan beras tersebut mewakili objek petani yang sesunguhnya karena memiliki kemiripan dengan bentuk aslinya yaitu penggambaran seorang petani.

2. Indeks berupa manusia memakai caping (topi petani), memegang tulisan "Darurat Agraria" dan satu tangan lainnya menggenggam seikat padi, serta dimana pada tubuh atau pakaian dari petani tersebut digambarkan dengan gedung industri yang padat serta kendaraan yang mengakibatkan polusi pada ilustrasi kemasan beras yang pertama. Serta manusia memakai caping (topi petani) sedang memikul dolar dan padi pada ilustrasi kemasan beras kedua, dimana kedua ilustrasi pada kemasan beras tersebut dikatakan sebagai indeks karena menggambarkan sebuah sebab akinbat dimana pada ilustrasi yang pertama digambarkan pakaian petani dipenuhi gedung industri dan jalanan yang penuh 
kendaraan yang artinya lahan pertanian telah beralih fungsi sehingga terjadinya darurat agraria. Sedangkan ilustrasi pada kemasan kedua menggambarkan dolar dan padi tidak berimbang dimana digambarkan dolar lebih berat daripada padi, sehingga banyak petani terpaksa menjual lahan sawahnya karena dolar lebih unggul serta berkuasa, yang mana keadaan tersebut juga mengakibatkan petani tercekik yang digambarkan dasi berbentuk ular yang melilit di leher petani tersebut.

3. Simbol antara lain caping (topi petani) serta padi pada ilustrasi kemasan beras yang pertama dan kedua merupakan simbol dari pertanian itu sendiri, dan pada ilustrasi kemasan kedua ada dua simbol tambahan yaitu dolar dan dasi berbentuk ular. Dolar adalah simbol uang, dimana uang bisa dingunakan membeli apa saja yang diinginkan termasuk membeli sawah dan merubahnya menjadi Gedunggedung serta jalan. Kemudian dasi berbentuk ular merupakan simbol dari pengusaha atau penguasa yang memiliki sifat seperti ular melilit serta mencekik petani sebagai rakyat kecil.

Saran yang dapat disampaikan berkaitan dengan penelitian yang dilakukan oleh penulis adalah sebagai berikut, melalui penelitian ini diajukan beberapa saran, baik kepada peneliti selanjutnya diharapkan penelitian ini menjadi refrensi agar kedepanya lebih banyak lagi penelitian yang berkaitan dengan analisis semiotika pada ilustrasi kemasan beras Ecoko Green Project karya dari Oka Astawa yang menyuarakan isu pertanian, atau karya-karya desain lainnya. Pemilihan objek yang digunakan Oka Astawa sebagai ilustrasi pada kemasan beras Ecoko Green Project sangat mewakili fenomena yang sedang terjadi terhadap petani dan lahan pertanian yang ada di Bali. Bagi para desainer yang ingin merancang sebuah desain disarankan agar bisa memilih ilustrasi yang tepat agar tanda makna komunikasi viual yang terkandung didalamnya bisa sesuai dengan isi pesan yang ingin disampaikan sehingga pesan tersebut bisa diterima dan dipahami oleh target sasaran.

\section{UCAPAN TERIMA KASIH}

Terimakasih kepada I Gede Oka Astawa selaku seniman yang menggagas Ecoko Green Project ini karena telah melakukan suatu program nyata mengenai masalah pertanian yang terjadi di Bali dan sangat menginspirasi penulis untuk turut serta berkarya dan membuat aksi yang nyata untuk kampung halaman. Terimakasih juga karena melalui Ecoko Green Project ini penulis bisa mengkaji karya ilustrasi desain kemasan beras dari Ecoko Green Project ini, sehingga dapat dijadikan jurnal sebagai syarat untuk mengikuti ujian tugas akhir. Penulis juga mengucapkan terimakasih kepada Redaksi DESKOVI: Art and Design Juornal yang telah menerima dan menerbitkan jurnal ini.

\section{DAFTAR PUSTAKA}

Klimchuk, Marianne dan Sandra A. Krasovec. 2006. Desain Kemasan. Jakarta: Erlangga.

Kotler dan Keller. 2009. Manajemen Pemasaran. Jilid I. Edisi ke 13. Jakarta: Erlangga.

Kris Budiman. 2011. Semiotika Visual konsep, Isu, dan problem Ikonitas. Yogyakarta: Jalasutra.

Rangkuti, Freddy. 2010. Analisis SWOT: Teknik Membedah Kasus Bisnis. Jakarta: Gramedia.

Simamora, Bilson. 2007. Panduan Riset dan Perilaku Konsumen. Jakarta: Gramedia.

Uhar Suharsaputra. 2014. Metode Penelitian, kuantitatif, Kualitatif, dan Tindakan. Bandung: PT.Refika Aditama.

Wisnuardhana, Ida Bagus (2020, Mei 5). Lahan Sawah di Bali Berkurang 550 Hektare per Tahun, Tabanan Tertinggi. Dikutip dari https://bali.idntimes.com/news/bali/imamrosidi n/kondisi-sawah-di-bali-tahun

"Pengertian dan Masalah Kritik Sosial". KajianPustaka.com. Diakses tanggal 2020-0505 . 